\title{
21003 微細径超硬合金の精密磁気研磨
}

\section{Precision Cylindrical Magnetic Abrasive Finishing of a Cemented Carbides}

\author{
正 進村 武男（宇都宮大院）正 山口 ひとみ（宇都宮大） \\ ○学 小阪 和広 (宇都宮大院) \\ Takeo SHINMURA, Utsunomiya University, 7-1-2 Yoto, Utsunomiya, Tochigi \\ Hitomi YAMAGUCHI \\ Kazuhiro KOSAKA
}

\begin{abstract}
The implementability of the high precision magnetic abrasive finishing technology over cemented carbide slender work used for the diameter punch of detailed was examined. In this paper, the effects of the clearance between work surface and magnetic pole, and the particle diameter of diamond abrasive and ferrous particle are examined on the finishing characteristics. As a result, it's effective find out that the clearance was narrow and the particle diameter of diamond abrasive and ferrous particle was small. It's concretely, in the work-pole clearance on $0.5 \mathrm{~mm}$ and mixed abrasive at the diamond paste whose mean particle diameter is $0.25 \mu \mathrm{m}$ and a ferrous particle using iron particles whose mean particle diameter is $30 \mu \mathrm{m}, 1.9 \mu \mathrm{mRz}$ of surface roughness has been improved to $0.07 \mu \mathrm{mRz}$, and 1.2 $\mu \mathrm{m}$ of roundness has been improved to $0.6 \mu \mathrm{m}$. These results and a machining mechanism are reported.
\end{abstract}

Key Words : Magnetic Abrasive Finishing, Cylindrical Finishing, Surface Roughness, Material Removal, Cemented Carbide

\section{1. 緒 言}

医療機器やコンピュータ, カメラ, AV 機器などの各種精 密機器製造産業において製品の高性能化, 小型軽量化が求め られている。これを実現するには微細精密部品の高精度微細 加工技術が必要不可欠であり, 新たな技術開発が切望されて いる. このニーズに応えるため, 工作物の形状精度を維持し ながら面精度を向上できる特長を有する磁気研磨法の適用 が期待される.

本研究は, 微細径の工作物を研磨加工対象として研究を進 めた．本報は，微細径パンチに用いられる超硬合金丸棒を加 工対象として, 高精度精密磁気研磨技術の実現性について検 討した。まず， $0.9 \mathrm{~mm}$ 径の細径超硬合金丸棒の精密磁気研磨 実験を行い, 微細径丸棒に対する精密磁気研磨の可能性を調 ベた.

\section{2. 実験装置及び実験条件の選定}

実験装置は磁極振動方式磁気研磨装置 ${ }^{1) を}$ 用いて実験を行 った．表 1 に実験条件を，表 2 に実験条件の組み合わせを示 す. 本加工法の重要因子として, 加工部の磁場分布および磁 場強度, 供給する混合砥粒の粒径が挙げられる。加工間隙, 研磨材及び強磁性体粒子の粒径が研磨特性に及ぼす影響を 明らかにするため, 表 2 に示すように, 条件 $\mathrm{A}$ (加工間隙 $1 \mathrm{~mm}$, 強磁性体粒子径 $75 \mu \mathrm{m}$, ダイヤモンド砥粒径 $1 \mu \mathrm{m}$ ), 条件 $\mathrm{B}$ （加工間隙 $0.5 \mathrm{~mm}$, 強磁性体粒子径 $75 \mu \mathrm{m}$, ダイヤモンド砥 粒径 $1 \mu \mathrm{m}$ ), 条件 C (加工間隙 $0.5 \mathrm{~mm}$, 強磁性体粒子径 $75 \mu \mathrm{m}$, ダイヤモンド砥粒径 $0.25 \mu \mathrm{m}$ ），条件 D（加工間隙 $0.5 \mathrm{~mm}$, 強 磁性体粒子径 $30 \mu \mathrm{m}$, ダイヤモンド砥粒径 $0.25 \mu \mathrm{m}$ ）の 4 種類 の条件を設定して研磨実験を行った. 表面粗さの時間的変化 が現れなくなった時点で実験を中止した.

\section{3. 実験結果及び考察}

図 1 に表面粗さと加工量の時間的変化を, 図 2 に加工前と 加工後の工作物表面の SEM 観察写真を示す. 加工間隙につ いて条件 $\mathrm{A}$ と $\mathrm{B}$ を比較すると, 条件 $\mathrm{B}$ において表面粗さ $R z$ が条件 Aのときよりも早く収束し始めたが, 值にばらつきが
Table 1 Experimental conditions

\begin{tabular}{|c|c|}
\hline Work & $\begin{array}{l}\text { Non-ferromagnetic cemented carbide bar, } \\
(\varnothing 0.9 \times 30 \mathrm{~mm})\end{array}$ \\
\hline Work revolution & $30000 \min ^{-1}$ \\
\hline Magnetic pole & SS400 \\
\hline Magnet & $\begin{array}{l}\text { Nd-Fe-B rare earth permanent magnet } \\
(20 \times 10 \times 12 \mathrm{~mm})\end{array}$ \\
\hline $\begin{array}{l}\text { Axial vibration of } \\
\text { magnetic poles }\end{array}$ & $\begin{array}{l}\text { Frequency }: 5 \mathrm{~Hz} \\
\text { Amplitude }: 1 \mathrm{~mm}\end{array}$ \\
\hline $\begin{array}{l}\text { Mixed-type } \\
\text { magnetic abrasives }\end{array}$ & $\begin{array}{l}\text { Ferrous particles }: 0.8 \mathrm{~g} \\
\quad(\text { mean diameter }: 30,75 \mu \mathrm{m}) \\
\text { Diamond paste }: 0.2 \mathrm{~g} \\
\quad(\text { mean diameter }: 0.25,1 \mu \mathrm{m})\end{array}$ \\
\hline Lubricant & Water-soluble grinding fluid $: 0.2 \mathrm{~mL}$ \\
\hline Work-pole clearance & $0.5,1.0 \mathrm{~mm}$ \\
\hline Finishing time & $3 \mathrm{~min}$ \\
\hline
\end{tabular}

Table 2 Combination of particle diameters and clearance

\begin{tabular}{|l|c|c|c|c|}
\hline & A & B & C & D \\
\hline Ferrous particles $(\mu \mathrm{m})$ & 75 & 75 & 75 & 30 \\
\hline Diamond abrasives $(\mu \mathrm{m})$ & 1 & 1 & 0.25 & 0.25 \\
\hline Work-pole clearance $(\mathrm{mm})$ & 1 & 0.5 & 0.5 & 0.5 \\
\hline
\end{tabular}

見られた. また, 加工量も 2 倍近い值が観察され, SEM 観 察によると, 研磨面が粗面化している様が確認できた。 これ は, 加工間隙の隇少による研磨圧力の増加に伴い, 砥粒切れ 刃が深く切り込み研磨が行われるが, 超硬合金は焼結材であ ため, 焼結粒子が脱落したものと考えられる. このため, 研 磨時間の短縮には加工間隙の減少は有効だが, それに伴い砥 粒の粒径を小さくしなければならないことが推察される.

砥粒径について条件 B と条件 C を比較すると, 表面粗さ $R z$ のばらつきは改善されたが, 研磨時間の短縮や仕上げ面の 


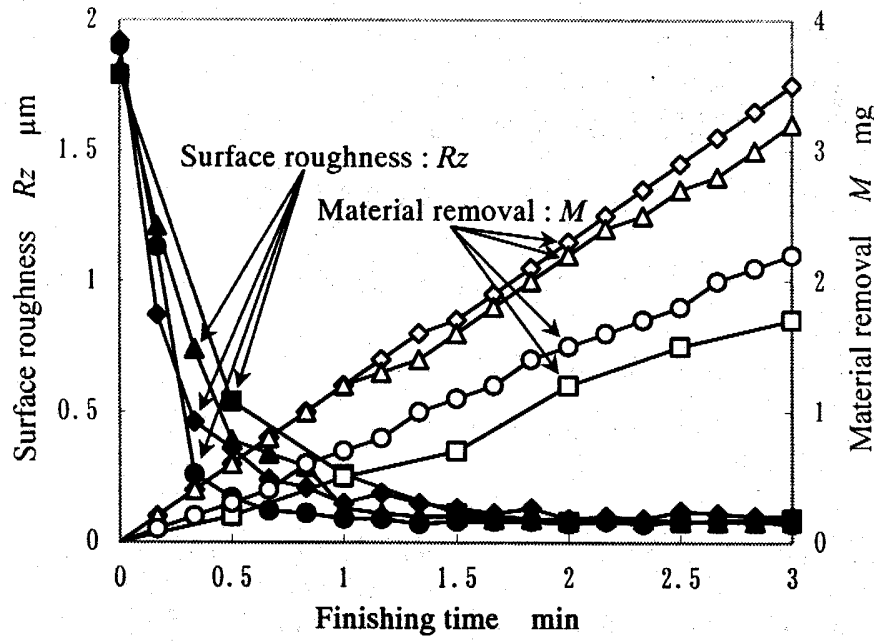

\begin{tabular}{llll|}
$-R z$ & Combination (A) & $-\square M$ & Combination (A) \\
$\leftarrow-R z$ & Combination (B) & $\checkmark M$ & Combination (B) \\
$-R z$ & Combination (C) & $-M$ & Combination (C) \\
$-R z$ & Combination (D) & $-M$ & Combination (D) \\
\hline
\end{tabular}

Fig. 1 Changes in surface roughness and material removal with finishing time

向上には至らなかった.これは, 砥粒径の縮小により切り込 み深さが減少し, 面精度に変化が現れたためと考察される. 加工量に関しては, 砥粒径の縮小に伴い研磨接触面積が増加 したため, 切り込み量が隇少しても加工量はあまり変わらな かったものと考えられる. また，強磁性体粒子の粒径は変わ らないため, 総研磨圧力も変化がなく, 研磨時間の短縮に至 らなかったものと考えられる。

強磁性体粒子径について条件 C と D 比較すると, 表面 粗さ $\mathrm{Rz}$ については值のばらつきもなく，ともに $0.07 \mu \mathrm{m} R z$ に収束し，条件 Dにおいて加工時間も短縮された．また，加 工面の SEM 観察によると，条件 D の方では粗面が改善され

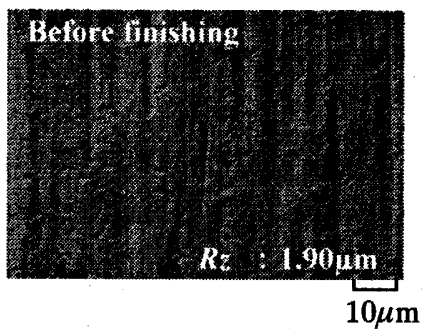

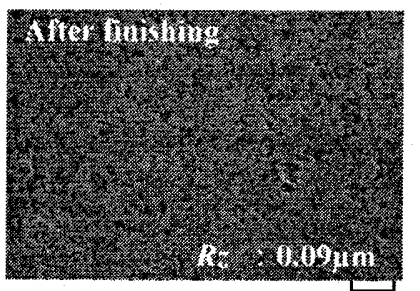

Combination (A) $10 \mu \mathrm{m}$

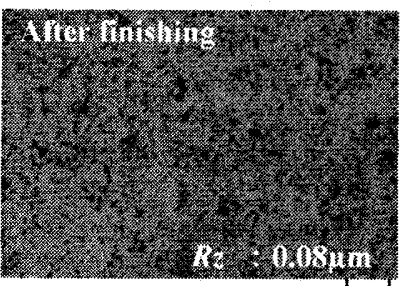

Combination (C) $10 \mu \mathrm{m}$

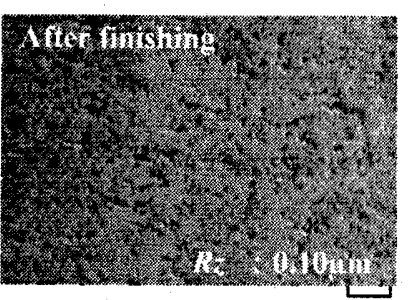

Combination (B) $10 \mu \mathrm{m}$

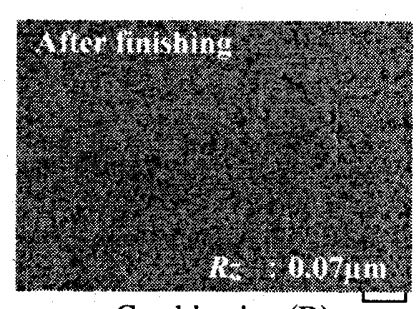

Combination (D) $10 \mu \mathrm{m}$
Fig. 2 SEM photos of workpiece surface before and after finishing
ているのが確認できる。これらは, 強磁性体粒子径を減少さ せたことにより，研磨時の砥粒を巻き込む量や個々の砥粒に かかる研磨圧力が変化したためと考えられる。

これらの結果から, 研磨時間の短縮には研磨圧力の増加が 有効であり, 加工間隙を小さくすることにより容易に実現が 可能である．仕上げ面の粗面化を防ぐには，強磁性体粒子お よび砥粒の粒径も縮小しなければならないことがわかった。

\section{4. 真円度}

本研究の対象工作物である細径パンチにおいて, 形状は真 円かつ真直であることが望ましい，加工中の真円度を測定し， 工作物の形状精度の変化について検討した. 実験条件は前節 において良好な結果を示した条件Dとした。

図 3 に真円度と加工量の時間的変化を示す. 真円度につい て加工域の中心を測定したところ, 加工前の $1.2 \mu \mathrm{m}$ が加工後 に $0.6 \mu \mathrm{m}$ に改善された. また, 研磨量は加工時間にほぼ比例 して增加している. この結果から，真円度は研磨量の増加と ともに次第に改善されることがわかる.

磁気研磨法において，混合砥粒が形成する粒子ブラシ ${ }^{2)}$ は微細な粒子から構成されているため, その挙動の自由度は 高く, さらに粒子ブラシは磁極先端に近くなるほど磁力が高 くなるため, 粒子ブラシの用性も高くなる.このため, 磁極 先端に近くなるほど研磨力が高くなる. 本加工法では, 磁極 間の中心に工作物を設置しているため, 工作物形状の凹部分 よりも凸部分をより研磨加工することとなる. 結果, 非磁性 の円筒形工作物の精密磁気研磨法は, 工作物の形状精度を向 上させることができたものといえる.

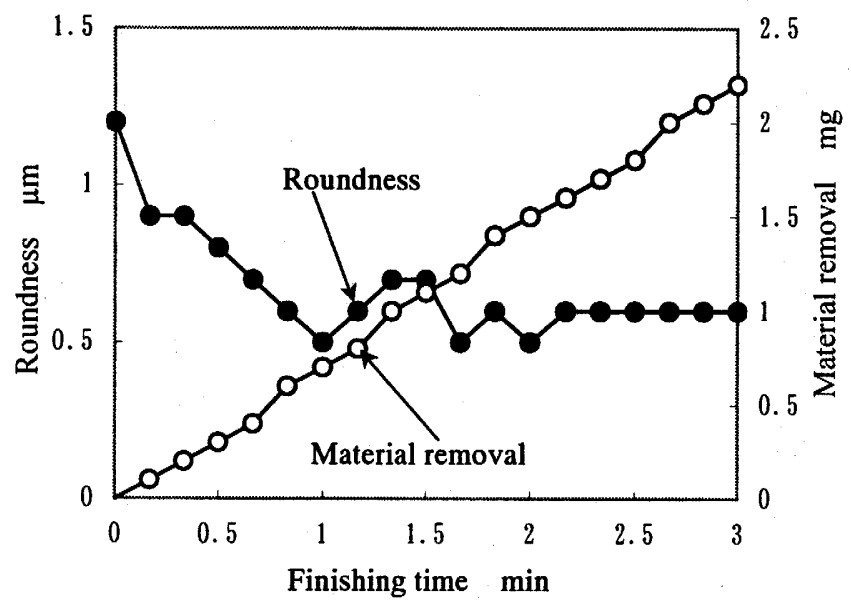

Fig. 3 Changes in roundness and material removal with finishing time

\section{5. 結 带}

外径 $0.9 \mathrm{~mm}$ の非磁性超硬合金丸棒を精密磁気研磨法によ り, 短時間で精密表面仕上げが可能であり，かつ形状精度を 向上させることができることを示した.

今後は, 微細径および磁性超硬合金丸棒への適用について 検討していく予定である.

\section{謝 辞}

本研究の一部は文部科学省都市エリア産学官連携促進事業 「宇都宮・県央エリア」の支援を受けた. お礼申し上げます。

\section{文 献}

(1). 進村, 山口, 小阪 : 日本機械学会関東支部ブロック合 同講演会-2004 宮代-講演論文集, p153.

(2). 進村, 山口: 科学と工業, 74, 4, (2000)169. 